\title{
KONFIRMASI JENIS DAN KERAGAMAN GENETIK SENGON RESISTEN DAN RENTAN INFEKSI KARAT TUMOR MENGGUNAKAN PENANDA DNA KLOROPLAS \\ (Species Confirmation and Genetic Diversity of Gall-Rust Resistant and Susceptible Sengon Using Chloroplast DNA Marker)
}

\author{
Hasyyati Shabrina ${ }^{1 *}$, Ulfah J. Siregar ${ }^{2}$, Deden D. Matra ${ }^{3}$, \\ dan/and Iskandar Z. Siregar ${ }^{2 *}$ \\ ${ }^{1}$ Program Studi Silvikultur Tropika, Sekolah Pascasarjana IPB University, \\ Jl. Ulin, Kampus IPB Dramaga Bogor 16680 West Java, Indonesia. Telp : +62 2518622642 ; \\ Email: silvikultur@apps.ipb.ac.id \\ ${ }^{2}$ Departemen Silvikultur, Fakultas Kehutanan IPB University \\ Jl. Ulin, Kampus IPB Dramaga Bogor 16680 West Java, Indonesia. Telp : +62 251 8622642; \\ Email: silvikultur@apps.ipb.ac.id \\ ${ }^{3}$ Departemen Agronomi dan Hortikultura, Fakultas Pertanian IPB University \\ J1. Meranti, Kampus IPB Dramaga Bogor 16680 West Java, Indonesia. Telp : +62 251 8629353; \\ Email: agrohort@apps.ipb.ac.id \\ E-mail :*hasyyati_shabrina@apps.ipb.ac.id; ulfahjs@apps.ipb.ac.id; \\ dedenmatra@apps.ipb.ac.id; *siregar@apps.ipb.ac.id
}

Tanggal diterima: 27 Juni 2020; Tanggal direvisi: 16 Oktober 2020; Tanggal disetujui: 19 Oktober 2020

\begin{abstract}
Sengon (Falcataria moluccana) plantations, particularly in Java, have been facing threats from gall-rust disease caused by the pathogen Uromycladium falcatariae, which has caused considerable economic losses. Other species with morphological similarities with $\underline{\mathrm{F}}$. moluccana raises the question of whether the infected and non-infected sengon are the same species. This study aimed to confirm the haplotype of infected and non-infected sengon by gall-rust and compare them with a morphologically similar species of Albizia chinensis using the psbA-trnH intergenic spacer region molecular marker on chloroplast DNA. Wet wood samples from 32 infected plants and 32 non-infected plants were collected from Bogor and Ciamis, West Java, for analysis and comparison with A. chinensis sequences from the same gene region. The results showed that the infected and non-infected sengon came from the same haplotype with a genetic distance of 0 and InDel diversity of 0,031. Meanwhile, from 380 parallel aligned sites, there were 27 different sites between $\underline{\mathrm{F}}$. moluccana and $\underline{\mathrm{A}}$. chinensis. The genetic distance of the two species was classified as very low at 0.017. The psbA-trnH intergenic spacer region sequences of sengon in this study were the first to be uploaded to GenBank and can be accessed with accession numbers of LC456638.1 to LC456701.1.
\end{abstract}

Keywords: Chloroplast DNA, gall-rust, psbA-trnH intergenic spacer, sengon

\begin{abstract}
ABSTRAK
Hutan tanaman sengon (Falcataria moluccana), khususnya di Pulau Jawa, pada umumya menghadapi serangan penyakit karat tumor yang disebabkan oleh patogen Uromycladium falcatariae, sehingga menimbulkan kerugian ekonomi yang cukup besar. Adanya spesies lain yang memiliki kemiripan morfologi dengan F. moluccana menimbulkan pertanyaan
\end{abstract}


apakah sengon yang terserang dan tidak terserang karat tumor merupakan jenis yang sama. Penelitian ini bertujuan untuk mengonfirmasi jenis sengon yang terserang dan tidak terserang karat tumor dan membandingkan dengan spesies yang mirip secara morfologi, yaitu Albizia chinensis menggunakan penanda molekuler daerah psbA-trnH intergenic spacer pada DNA kloroplas. Sampel kayu basah dari 32 tanaman terserang dan 32 tanaman yang tidak terserang karat tumor diambil dari Bogor dan Ciamis, Jawa Barat, untuk dianalisis dan dibandingkan dengan sekuens A. chinensis dari wilayah gen yang sama. Hasil analisis menunjukkan bahwa sengon yang terserang dan tidak terserang berasal dari haplotipe yang sama dengan jarak genetik 0 dan keragaman InDel sebesar 0,031. Sementara itu, dari 380 situs yang sejajar, terdapat 27 situs yang berbeda antara F. moluccana dan A. chinensis. Jarak genetik kedua jenis tersebut tergolong sangat rendah yaitu 0,017 . Sekuens daerah $p s b A-t r n H$ intergenic spacer sengon dalam penelitian ini merupakan yang pertama diunggah di GenBank dan dapat diakses dengan nomer aksesi LC456638.1 sampai LC456701.1.

\section{Kata kunci: DNA kloroplas, karat tumor, psbA-trnH intergenic spacer, sengon}

\section{PENDAHULUAN}

Sengon (Falcataria moluccana (Miq.) Barneby \& J.W.Grimes) merupakan spesies dengan sebaran alami di Indonesia, yaitu di Maluku, Papua, dan Sulawesi Selatan (Krisnawati, et al., 2011). Sengon merupakan jenis yang menempati urutan lima besar dalam produksi kayu bulat Indonesia tahun 2017 (Badan Pusat Statistik, 2018) serta menyumbang 54,87\% dari total kayu bulat yang dihasilkan di Pulau Jawa (Badan Pusat Statistik, 2019). Produksi sengon yang tinggi di Indonesia dikarenakan spesies tersebut merupakan jenis yang memiliki sifat cepat tumbuh, sehingga banyak ditanam di hutan tanaman, terutama hutan rakyat khususnya di Jawa. Sifat cepat tumbuh tersebut menyebabkan cepatnya return ekonomi yang diperoleh oleh petani sengon et al., 2013). Kayu sengon dimanfaatkan untuk papan penyekat, tiang pengecoran semen dalam konstruksi, industri korek api dan pensil, bahan baku pulp dalam industri pulp dan kertas, kayu lapis, konstruksi ringan, peti kemas, kerajinan dan kayu energi (Hardiatmi, 2010). Selain itu, serbuk gergajinya juga dimanfaatkan sebagai media untuk budi daya jamur tiram putih (Reyeki, 2013).

Berkembangnya hutan tanaman sengon dengan pesat juga diikuti dengan adanya ancaman penyakit karat tumor yang disebabkan cendawan patogen Uromycladium falcatariae (Doungsa-ard, et al., 2015). Penyakit tersebut menyebabkan pertumbuhan jaringan yang abnormal yang dapat menyebabkan kematian jaringan bahkan tanaman, sehingga berdampak pada menurunnya kualitas dan kuantitas produksi kayu (Budiman \& Rianti, 2012). Beberapa penelitian terdahulu (Baskorowati, et al., 2012; Baskorowati \& Nurrohmah, 2011; Rohandi \& Gunawan, 2019; Setiadi, et al., 2014) menunjukkan adanya provenans tertentu yang lebih toleran terhadap serangan karat tumor tetapi hasil penelitian tersebut tidak dianalisis secara molekuler.

Selain F. moluccana, saat ini beredar juga sengon merah (Albizia chinensis (Osbeck) Merr.) yang memiliki kenampakan mirip dengan F. moluccana dari segi warna dan bentuk anak daun serta bentuk pohon (US Forest Service Pacific Island Ecosystems Risk, 2013; 2018). Sengon merah di Indonesia juga mulai dibudidayakan di beberapa tempat, diantaranya, yaitu Jawa Tengah (Purnomo, et al., 2018), Sumatera Utara (Utomo, et al., 2019), Banten (Iskandar et al., 2018), dan Bandung (Withaningsih et al., 2019). Akan tetapi, meskipun memiliki kemiripan secara morfologi, sifat fisik dan mekanik kayu sengon dan sengon merah agak berbeda (The International Tropical Timber Organization, 2020a; 2020b). Sementara itu, penggantian jenis bahan baku kayu 
sengon dengan kayu lain akan berimbas pada penambahan biaya untuk penggantian alat untuk menyesuaikan sifat fisik kayu. Selain itu, permintaan pasar terhadap produk-produk dari kayu sengon juga belum dapat digantikan oleh kayu lain, sehingga pengendalian serangan penyakit karat tumor pada hutan tanaman sengon perlu dilakukan untuk menjaga produktivitas kayu sengon dan kualitas kayu yang dihasilkan agar pasokan kayu ke industri tetap terjaga keberlanjutannya.

Hal lain yang menyebabkan pentingnya dilakukan konfirmasi genetik, yaitu dalam beberapa penelitian, sengon diberikan keterangan nama ilmiah yang sama dengan sengon merah (A. chinensis (Artati, Y., Jaung, W., Juniwaty, K.S., Andini, S., Lee, S.M., Segah, H., \& Baral, H., 2019; Ota, 2019; Surjosatyo A., Dewantoro, B.R., Saragih, B.R., Nainggolan, F., Dwianto, W., \& Darmawan, T., 2018). Selain itu, muncul pertanyaan apakah sengon yang terserang dan tidak terserang karat tumor merupakan sengon jenis yang sama. Oleh karena itu, perlu juga dilakukan analisis molekuler untuk identifikasi apakah sengon yang tidak terserang penyakit tersebut merupakan jenis sengon yang berbeda.

Salah satu metode yang dapat digunakan untuk mengonfirmasi suatu spesies, yaitu penggunaan penanda molekuler untuk DNA barcoding. Penanda molekuler yang dapat digunakan untuk tujuan tersebut salah satunya, yaitu menggunakan penanda dari DNA kloroplas yang sifatnya merupakan conserved region. Daerah psbA-trnH intergenic spacer merupakan sekuens pendek pada angiospermae dengan panjang 200-500 pasang basa (basepair/bp) (Štorchová \& Olson, 2007) Sekuens tersebut dapat teramplifikasi dengan baik pada DNA yang terdegradasi dari kayu (Yu, et al., 2016). Daerah tersebut dapat menjadi kandidat DNA barcode yang lebih variatif dibandingkan penanda matK dan $r b c L$ (Newmaster \& Ragupathy, 2009) dan memiliki efisiensi identifikasi yang lebih baik dibandingkan matK, $r b c L$, dan ITS (Pang et al., 2012)

Penelitian ini bertujuan untuk mengkonfirmasi jenis sengon yang terserang dan tidak terserang karat tumor menggunakan penanda molekuler yang berasal dari daerah psbA-trnH intergenic spacer pada DNA kloroplas dan menganalisis keragaman genetik sengon berdasarkan penanda tersebut.

\section{METODOLOGI}

\section{A. Lokasi Penelitian}

Sampel diambil dari 32 lokasi yang terdiri dari 16 lokasi di Ciamis dan 16 lokasi di Bogor, Jawa Barat. Sepasang sampel yang terdiri dari satu pohon yang terserang (rentan) karat tumor dan satu pohon yang tidak terserang (resisten) (Lelana, 2018) yang selanjutnya dalam penelitian ini diberi kode "R" untuk sampel resistan dan "S" untuk sampel rentan, diambil dari setiap plot. Adapun intensitas penyakit karat tumor pada 32 plot tersebut berkisar antara 0,87-91,67\% (Shabrina, 2020). Kedua pohon tersebut harus benar-benar berdekatan untuk meminimalisir bias lingkungan. Lokasi penelitian dapat dilihat pada Gambar 1.

\section{B. Metode}

\section{Pengambilan sampel}

Sebanyak 64 sampel dikumpulkan dari 32 plot dengan masing-masing dua tanaman untuk setiap plot. Sampel yang dikoleksi berupa kayu dari tanaman yang terserang dan tanaman yang tidak terserang karat tumor dan keduanya sangat berdekatan. Tanaman yang diambil kayunya berumur 24 tahun. Kriteria tanaman yang diambil sebagai sampel mengacu pada Baskorowati et al., (2012), yaitu untuk sengon yang tidak terserang karat tumor memiliki skor keparahan 0 sedangkan untuk yang terserang memiliki skor 4-5. Sampel kulit bagian dalam dan kayu luar dikumpulkan dengan cara dicongkel menggunakan 
parang. Sampel kemudian dibersihkan dengan alkohol kemudian dimasukkan ke dalam plastik ziploc berisi gel silika dan sesegera mungkin disimpan dalam freezer dengan suhu minimal $-20{ }^{\circ} \mathrm{C}$.

\section{Ekstraksi DNA}

DNA diekstraksi menggunakan metode (Shabrina, H., Siregar, U.J, Matra, D.D, Siregar, I.Z., Kamiya, K., 2019), yaitu tanpa menggunakan nitrogen cair. Kayu yang sudah diserut halus sebanyak $0,2 \mathrm{~g}$ kemudian dimasukkan ke dalam tabung mikro dan dibekukan pada suhu $-30^{\circ} \mathrm{C}$ selama 24 jam. Kayu dihancurkan menggunakan TissueLyzer II Qiagen dengan bantuan bola besi mikro (microbeads). Serbuk kayu kemudian dimasukkan ke dalam $500 \mu \mathrm{L}$ bufer ekstraksi yang dibuat menggunakan cetyl trimethyl ammonium bromide (CTAB) $10 \%$, polyvinyl pyrrolidon (PVP) $1 \%$, ethylenediamine tetraaceticacid (EDTA) $0.5 \mathrm{M}$, natrium klorida $(\mathrm{NaCl}) 5 \mathrm{M}$, Tris $1 \mathrm{M}$ dan $\beta$-merkaptoetanol $1 \%$. Campuran dalam tabung mikro dihomogenkan dengan vortex lalu diinkubasi pada suhu $65^{\circ} \mathrm{C}$ dalam waterbath selama satu jam dengan dibolakbalik setiap 15 menit. Setelah itu, tabung mikro sampel disentrifugasi dengan kecepatan $10.000 \mathrm{rpm}$ selama 10 menit. Supernatan kemudian dipindahkan ke tabung mikro baru dan ditambahkan klorofom:isoamilalkohol (24:1) sebanding dengan volume supernatan. Tabung mikro kemudian disentrifugasi dengan kecepatan 10.000 rpm selama 10 menit dan supernatan dipindahkan ke tabung mikro baru. Supernatan kemudian ditambahkan isopropanol dingin sebanyak $500 \mu \mathrm{L}$ dan $\mathrm{NaCl} 5 \mathrm{M}$ sebanyak $300 \mu \mathrm{L}$ kemudian diinkubasi selama minimal satu jam di freezer suhu $-20^{\circ} \mathrm{C}$. Setelah itu, tabung mikro sampel disentrifugasi dengan kecepatan $10.000 \mathrm{rpm}$ selama 10 menit. Cairan yang berada dalam tabung mikro dibuang, sehingga tersisa endapan DNA. Endapan tersebut dicuci dengan etanol $70 \%$ sebanyak $300 \mu \mathrm{L}$ kemudian disentrifugasi dengan kecepatan $10.000 \mathrm{rpm}$ selama 10 menit. Cairan etanol kemudian dibuang dan tersisa pelet DNA yang sudah bersih. Tabung mikro kemudian dikeringkan di dalam desikator berisi gel silika. DNA dilarutkan dengan menambahkan bufer Tris EDTA (TE) 1×. DNA hasil ekstraksi diuji pada gel agarosa $1 \%$ dengan bufer Tris Acetic Acid EDTA (TAE) 1×. Pewarnaan DNA pada agarosa dilakukan dengan perendaman dalam larutan ethidium bromida $(\mathrm{EtBr}) 0,5 \mu \mathrm{g} / \mathrm{ml}$. Visualisasi DNA dilakukan dengan UV transilluminator.

\section{Polymerase Chain Reaction (PCR)}

PCR dilakukan dengan primer trnH(GUG) (5'-ACTGCCTTGATCCACT TGGC-3') - psbA (5'- GCAAGCTCCATCT ACAAATGG-3') (Hamilton, 1999). Reaksi amplifikasi dilakukan menggunakan Go Taq mastermix (Promega) yang komposisinya disajikan pada Tabel 1 . PCR dilakukan dengan siklus: pre-denaturasi 2 menit pada suhu $95^{\circ} \mathrm{C}$; diikuti 35 siklus denaturasi 1 menit pada $95^{\circ} \mathrm{C}$, annealing 1 menit pada $55^{\circ} \mathrm{C}$, dan ekstensi selama 1 menit pada $72^{\circ} \mathrm{C}$; diikuti tahapan final extension selama 10 menit pada $72^{\circ} \mathrm{C}$. 
Hasyyati Shabrina, Ulfah J. Siregar, Deden D. Matra, dan/and Iskandar Z. Siregar

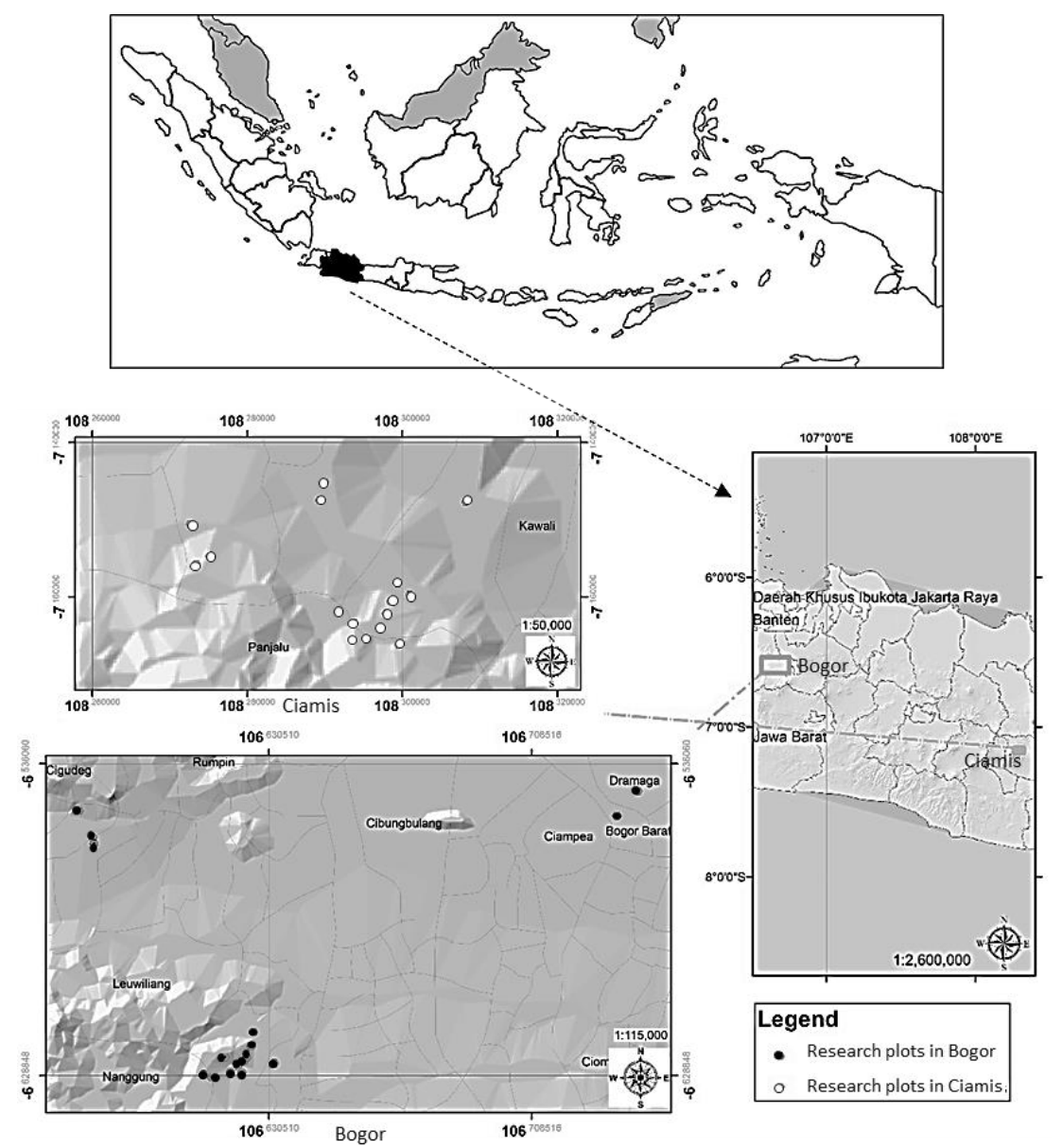

Gambar (Figure) 1. Peta lokasi pengambilan sampel (Sampling location map)

Tabel (Table) 1. Komposisi pereaksi PCR (PCR Reagan composition)

\begin{tabular}{|c|c|c|c|}
\hline No. & Komponen (Component) & $\begin{array}{c}\text { Volume (Volume) } \\
(\mu \mathrm{l})\end{array}$ & $\begin{array}{c}\text { Konsentrasi } \\
\text { (Concentration) }\end{array}$ \\
\hline & Primer trnH (trnH primer) & 1 & $10 \mathrm{pmol} / \mu \mathrm{L}$ \\
\hline 2. & Primer $p s b A$ ( $p s b A$ primer $)$ & 1 & $10 \mathrm{pmol} / \mu \mathrm{L}$ \\
\hline 3. & DNA cetakan (DNA template) & 1 & $25 \mathrm{ng} / \mu \mathrm{L}$ \\
\hline & Air bebas nuklease (Nuclease-free & 7 & - \\
\hline & water) & 10 & - \\
\hline & GoTaq mastermix & & \\
\hline & Total (Total) & 20 & - \\
\hline
\end{tabular}

\section{Sequencing}

Hasil amplifikasi kemudian dipurifikasi dengan metode exonuclease shrimp alkaline phosphatase (EXOSAP) (Werle, E., Schneider, C., Renner, M., Volker, M., \& Fiehn, W., 1994). Hasil purifikasi kemudian di PCR sekuens dengan primer $p s b A$ saja, mengikuti protokol dari BigDye $^{\mathrm{TM}}$ (ThermoFisher) dengan reaksi $6,5 \mu \mathrm{L}$ nuclease-free water, $1 \mu \mathrm{L} 5 \mathrm{x}$ sequencing buffer, $0,5 \mu \mathrm{L}$ primer, $1 \mu \mathrm{L}$
BigDye ver. 1.1, dan $1 \mu \mathrm{L}$ produk purifikasi. Siklus PCR seperti siklus PCR biasa dengan suhu annealing $50^{\circ} \mathrm{C}$ sebanyak 25 siklus. Tahapan selanjutnya, yaitu presipitasi ethanol untuk menghilangkan residu PCR. Pelet DNA hasil presipitasi kemudian ditambahkan dengan $13 \mu \mathrm{L}$ Formamide dan diinkubasi heat shock pada suhu $95^{\circ} \mathrm{C}$ selama tiga menit kemudian dipulihkan dengan pendinginan di es. Sampel kemudian disekuens dengan mesin alat ABI PRISM ${ }^{\circledR}$ 
3100 Genetic Analyzer (Applied Biosystem) dengan waktu satu jam untuk setiap sampel.

\section{Analisis Data}

Data hasil sekuens daerah $p s b$-trnH intergenic spacer kemudian diolah menggunakan perangkat lunak ATGC for Windows Genetyx v.13.0.2 (Genetyx Corporation, 2015). Analisis homologi dilakukan dengan membandingkan sekuens pada GenBank menggunakan basic local alignment search tools (BLAST) (https://blast.ncbi.nlm.nih.gov/Blast.cgi).

Analisis jarak genetik dilakukan dengan menentukan model algoritma terbaik dengan nilai Bayesian Information Criterion (BIC) (Bhat \& Kumar, 2010) dan Akaike Information Criterion corrected (AICc) (Hurvich \& Tsai, 1993) terendah. Model yang memenuhi kriteria tersebut dan memiliki jumlah variabel terkecil yaitu Tamura-3-parameter (Tamura, 1992) yang mempertimbangkan perbedaan mutation rate secara transversi dan transisi serta bias kandungan GC. Dendrogram dikonstruksi menggunakan metode maximum likelihood dengan 10.000 bootstraps (Neubig, et al., 2012). Analisis jarak genetik dan konstruksi dendrogram dilakukan dengan perangkat lunak MEGA-X (Kumar, et al., 2018). Analisis keragaman genetik dilakukan menggunakan perangkat lunak DNAsp (Rozas, J., Ferrer-Mata, A., SanchezDelBarrio, J.C., Guirao-Rico, S., Librado, P., Ramos-Onsins, S.E., \& Sanchez-Gracia, A., 2017). Sekuens kloroplas (plastid) sengon dan daerah psbA-trnH intergenic spacer sengon merah digunakan sebagai pembanding dalam analisis jarak genetik. Sekuens plastid sengon untuk identifikasi diunduh dari http://ncbi.nlm.nih.gov dengan kode aksesi NC_047364 (Zhang et al., 2020). Sekuens sengon merah diunduh dari http://ncbi.nlm.nih.gov dengan kode aksesi KR532922.1 dan KR532923.1 (Huang, X.C., Ci, X.Q., Conran, J.G., \& Li, J.et al., 2015).

\section{HASIL DAN PEMBAHASAN}

\section{A. Hasil}

Proses PCR berhasil dilakukan dan menghasilkan pita tunggal. Ukuran produk berkisar pada ukuran 500 bp (Gambar 2.). Hasil PCR tersebut dapat langsung digunakan pada tahap sequencing tanpa perlu melakukan ekstraksi produk PCR dari gel agarosa.

Produk PCR yang dihasilkan menggunakan penanda psbA-trnH intergenic spacer memiliki ukuran 457-458 bp dengan rata-rata kandungan GC sebesar $27,7 \%$. Sekuens yang diperoleh kemudian disejajarkan dengan sekuens pada basis data di GenBank menggunakan BLAST.

Hasil penyejajaran menunjukkan sekuens psbA-trnH intergenic spacer sengon memiliki kesamaan $100 \%$ dengan bagian dari plastid sengon (nukleotida nomor 124 sampai 547 dari 179.652 nukleotida) dan memiliki kemiripan yang tinggi (Total skor 100 dengan eigenvalue $0,0)$ dengan spesies-spesies lain dalam famili Fabaceae, terutama yang termasuk dalam clade Caesalpinioideae. Tiga sekuens selain sengon dengan kemiripan tertinggi berasal dari sekuens Pithecellobium clypearia (Total skor 767, Query cover 100\%) dan Parachidendron pruinosum (Total skor 752, 752, query cover $100 \%$ ). Sekuen yang dihasilkan dari penelitian merupakan sekuen psbA-trnH intergenic spacer dari sengon yang pertama kali diunggah di GenBank dan dapat diakses dengan nomor aksesi LC456638.1 sampai LC456701.1.

Analisis menggunakan model Tamura3-parameter menunjukkan bahwa tidak ada jarak genetik antar individu, populasi, dan region. Dendrogram (Gambar 3) menunjukkan individu-individu sengon tidak membentuk pengelompokan tertentu. Selanjutnya, hanya terdapat satu aksesi yang memiliki perbedaan insersi satu basa (B3_R, individu tidak terserang karat tumor dari Bogor) dari 64 aksesi. Berdasarkan analisis keragaman, dari seluruh aksesi hanya terdapat satu haplotipe (Keragaman 
haplotipe $\left.\mathrm{H}_{\mathrm{d}}=0,00\right)$. Insersi-Delesi atau InDel adalah mutasi yang berupa penambahan atau pengurangan basa nukleotida pada DNA, bahkan dengan ukuran <1kbp (Sehn, 2015). Analisis Insersi-delesi (InDel) menunjukkan hanya ada satu InDel yang terdeteksi dengan nilai keragaman InDel sebesar 0,031 sehingga terdapat dua haplotipe InDel. Perbedaan InDel disajikan pada Tabel 2. Insersi yang terjadi pada aksesi B3_R yaitu penambahan basa sitosin (C) pada nukleotida nomor 85 .
Hasil analisis jarak genetik antara sekuens sengon dengan sekuens A. chinensis menunjukkan sengon yang sampelnya diambil untuk penelitian ini sebagai aksesi semuanya merupakan jenis sengon yang sama dan terpisah dengan A. chinensis (Gambar 4). Sengon yang diambil sebagai pembanding bervariasi dari Bogor dan Ciamis serta aksesi yang terserang dan tidak terserang karat tumor, termasuk aksesi B3_R yang memiliki satu situs InDel. Jarak genetik antara sengon dengan A. chinensis berdasarkan region $p s b A$-trnH intergenic spacer sebesar 0,017 .

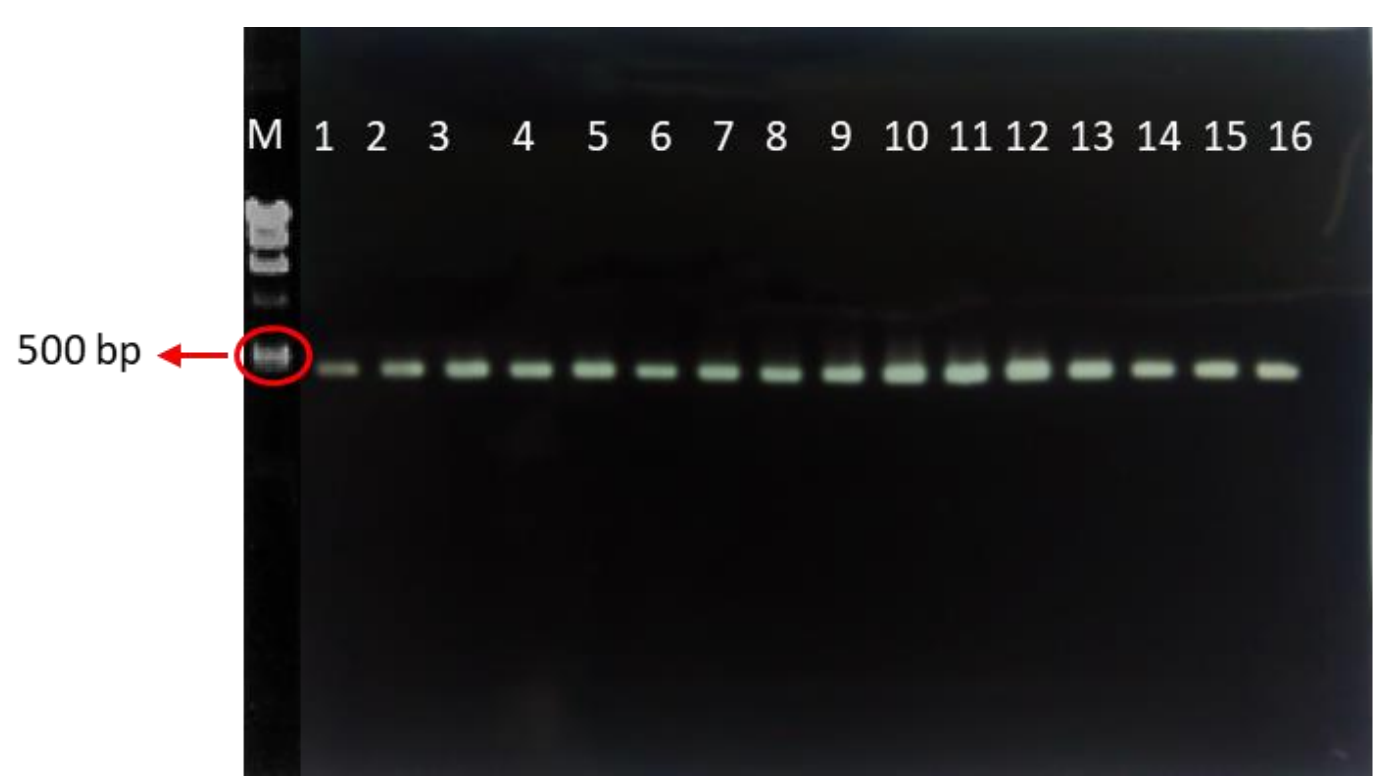

Gambar (Figure) 2. Hasil PCR psbA-trnH intergenic spacer pada sengon, M: $1 \mathrm{~kb} D N A$ ladder; 1, 3, 5, 7, 9, 11, 13, 15: sampel sengon resisten; 2, 4, 6, 8, 10, 12, 14, 16: sampel sengon rentan (PCR Results of psbA-trnH intergenic spacer on sengon, $M: 1 \mathrm{~kb}$ DNA ladder; 1, 3, 5, 7, 9, 11, 13, 15: resistant sengon sample; 2, 4, 6, 8, 10, 12, 14: susceptible sengon sample)

Tabel (Table) 2. Polimorfisme InDel pada sekuens psbA-trnH intergenic spacer sengon (InDel Polymorphism of psbA-trnH intergenic spacer sequence in sengon)

\begin{tabular}{|c|c|c|c|c|c|c|c|c|c|c|c|c|c|c|c|c|c|c|c|c|}
\hline \multirow{2}{*}{$\begin{array}{r}\text { Aksesi } \\
\text { (Accession) }\end{array}$} & \multicolumn{20}{|c|}{ Nomor situs (Site number) } \\
\hline & 76 & 77 & 78 & 79 & 80 & 81 & 82 & 83 & 84 & 85 & 86 & 87 & 88 & 89 & 90 & 91 & 92 & 93 & 94 & 95 \\
\hline 1. C15_R_psbA & A & $\mathrm{T}$ & A & A & $\mathrm{T}$ & $\mathrm{T}$ & A & A & $\mathrm{T}$ & - & $\mathrm{T}$ & $\mathrm{T}$ & A & $\mathrm{T}$ & $\mathrm{T}$ & $\mathrm{G}$ & $\mathrm{T}$ & $\mathrm{T}$ & $\mathrm{C}$ & $\mathrm{T}$ \\
\hline 2. C6_S_psbA & A & $\mathrm{T}$ & A & A & $\mathrm{T}$ & $\mathrm{T}$ & A & A & $\mathrm{T}$ & - & $\mathrm{T}$ & $\mathrm{T}$ & A & $\mathrm{T}$ & $\mathrm{T}$ & $\mathrm{G}$ & $\mathrm{T}$ & $\mathrm{T}$ & $\mathrm{C}$ & $\mathrm{T}$ \\
\hline 3. B12_R_psbA & A & $\mathrm{T}$ & $\mathrm{A}$ & A & $\mathrm{T}$ & $\mathrm{T}$ & A & A & $\mathrm{T}$ & - & $\mathrm{T}$ & $\mathrm{T}$ & A & $\mathrm{T}$ & $\mathrm{T}$ & $\mathrm{G}$ & $\mathrm{T}$ & $\mathrm{T}$ & $\mathrm{C}$ & $\mathrm{T}$ \\
\hline 4. B3_S_psbA & A & $\mathrm{T}$ & A & A & $\mathrm{T}$ & $\mathrm{T}$ & A & A & $\mathrm{T}$ & - & $\mathrm{T}$ & $\mathrm{T}$ & A & $\mathrm{T}$ & $\mathrm{T}$ & $\mathrm{G}$ & $\mathrm{T}$ & $\mathrm{T}$ & $\mathrm{C}$ & $\mathrm{T}$ \\
\hline 5. B3_R_psbA & $\mathrm{A}$ & $\mathrm{T}$ & A & $\mathrm{A}$ & $\mathrm{T}$ & $\mathrm{T}$ & $\mathrm{A}$ & $\mathrm{A}$ & $\mathrm{T}$ & & $\mathrm{T}$ & $\mathrm{T}$ & $\mathrm{A}$ & $\mathrm{T}$ & $\mathrm{T}$ & $\mathrm{G}$ & $\mathrm{T}$ & $\mathrm{T}$ & $\mathrm{C}$ & $\mathrm{T}$ \\
\hline
\end{tabular}

Keterangan (Remarks): B = Sampel dari Bogor (Sample from Bogor), $\mathrm{C}=$ Sampel dari Ciamis (Sample from Ciamis), $\mathrm{R}=$ Sampel resisten (resistant Sample), $\mathrm{S}=$ Sampel rentan (Susceptible sample) 


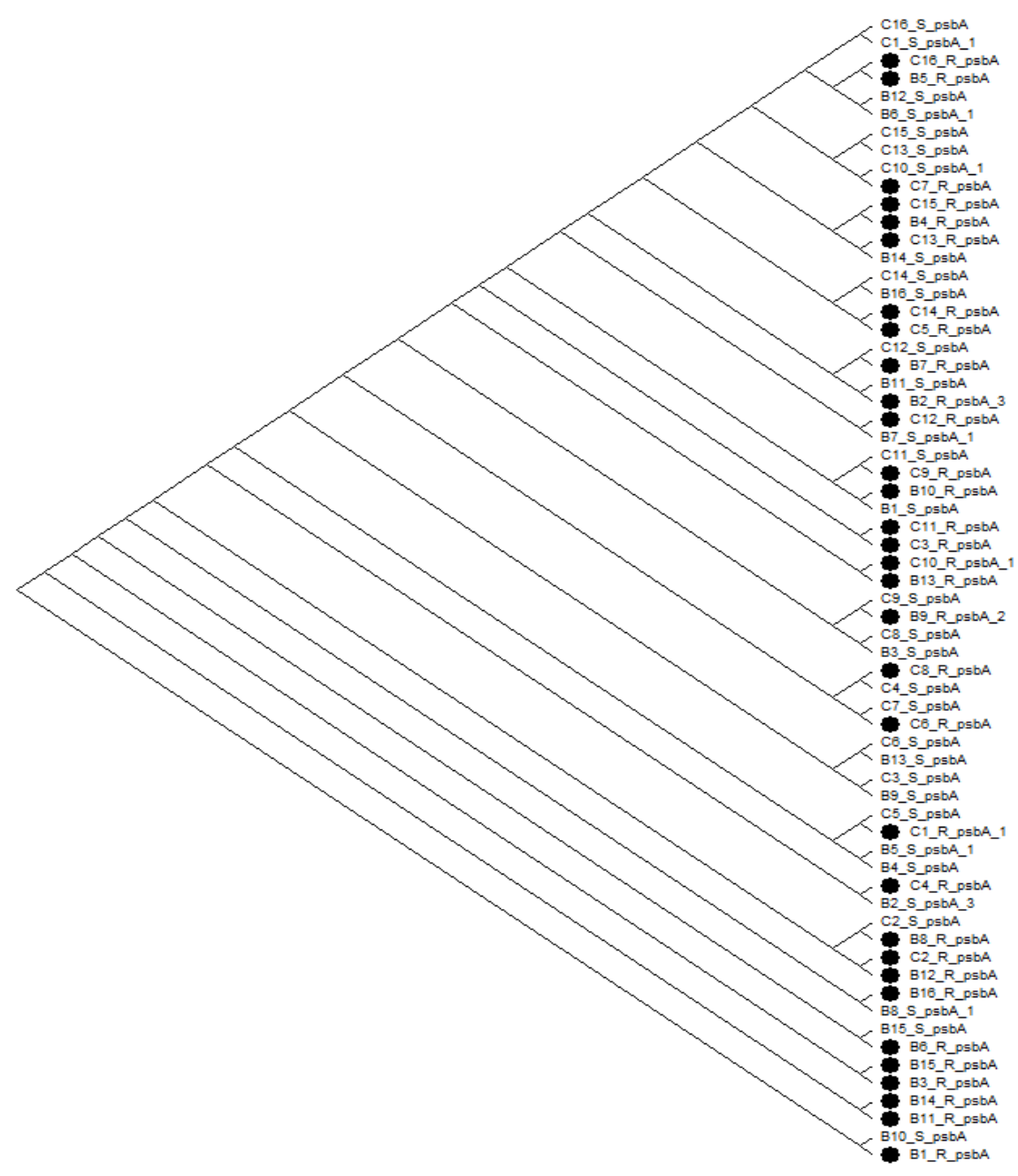

Gambar (Figure) 3. Dendrogram sengon berdasarkan sekuens daerah psbA-trnH intergenic spacer; •: sengon resisten. (Sengon dendrogram based on the psbAtrnH intergenic spacer region sequence; $\bullet$ : resistant sengon)

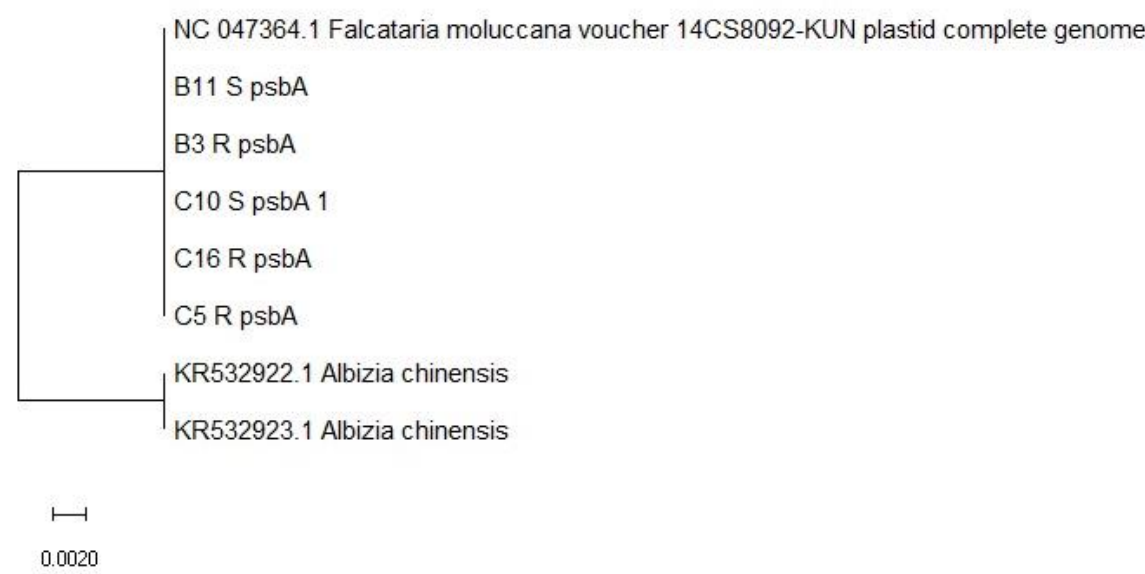

Gambar (Figure) 4. Dendrogram sengon dan sengon merah berdasarkan sekuens daerah psbA-trnH intergenic spacer (Sengon and red sengon dendrogram based on psbA-trnH intergenic spacer region sequences) 
Hasyyati Shabrina, Ulfah J. Siregar, Deden D. Matra, dan/and Iskandar Z. Siregar

Tabel (Table) 3. Polimorfisme sekuens daerah psbA-trnH intergenic spacer pada sengon dan sengon merah (Polymorphisms in psbA-trnH intergenic spacer region sequences of sengon and red sengon)

\begin{tabular}{|c|c|c|c|c|c|c|c|c|c|c|c|c|c|c|c|c|c|c|c|c|c|c|c|c|c|c|c|c|}
\hline \multirow{2}{*}{$\begin{array}{l}\text { Aksesi } \\
\text { (Accession) }\end{array}$} & \multicolumn{28}{|c|}{ Nomor situs (Site number) } \\
\hline & 14 & 465 & 50 & 53 & 150 & 152 & 153 & 154 & 155 & 156 & 157 & 198 & 202 & 203 & 204 & 205 & 206 & 207 & 238 & 261 & 319 & 339 & 345 & 346 & 347 & 348 & 349 & 350 \\
\hline - B11_S & $\mathrm{T}$ & $\mathrm{T}$ & - & A & $\mathrm{G}$ & $\mathrm{T}$ & A & A & G & A & A & $\mathrm{C}$ & $\mathrm{T}$ & $\mathrm{T}$ & $\mathrm{T}$ & $\mathrm{T}$ & $\mathrm{T}$ & $\mathrm{T}$ & $\mathrm{T}$ & - & A & G & - & - & - & - & - & - \\
\hline - C10_S & $\mathrm{T}$ & $\mathrm{T}$ & - & A & $\mathrm{G}$ & $\mathrm{T}$ & A & A & G & A & A & $\mathrm{C}$ & $\mathrm{T}$ & $\mathrm{T}$ & $\mathrm{T}$ & $\mathrm{T}$ & $\mathrm{T}$ & $\mathrm{T}$ & $\mathrm{T}$ & - & A & G & - & - & - & - & - & - \\
\hline - C16_R & $\mathrm{T}$ & $\mathrm{T}$ & - & A & $\mathrm{G}$ & $\mathrm{T}$ & A & A & G & A & A & $\mathrm{C}$ & $\mathrm{T}$ & $\mathrm{T}$ & $\mathrm{T}$ & $\mathrm{T}$ & $\mathrm{T}$ & $\mathrm{T}$ & $\mathrm{T}$ & - & A & G & - & - & - & - & - & - \\
\hline o KR532922.1 & $\mathrm{T}$ & $\mathrm{G}$ & - & C & - & - & - & - & - & - & - & A & - & - & - & - & - & - & C & A & C & A & G & A & A & G & G & A \\
\hline o KR532923.1 & $\mathrm{T}$ & G & - & C & - & - & - & - & - & - & - & A & - & - & - & - & - & - & C & A & C & A & G & A & A & G & G & A \\
\hline
\end{tabular}

Keterangan (Remarks) : $\bullet=$ Sampel sengon F. moluccana (Sengon F. moluccana samples), o=Sampel sengon merah A. chinensis (Red sengon samples $\underline{\text { A. }} \underline{\text { chinensis) }}$

\section{B. Pembahasan}

Pada angiospermae, daerah $p s b A-t r n H$ intergenic spacer yang merupakan daerah non-coding, adalah salah satu daerah yang banyak digunakan untuk DNA barcoding dan dapat mengamplifikasi sampel dari patahan akar yang sangat kecil yang di ambil dari dalam tanah (Kress, 2017). Region tersebut merupakan salah satu bagian dari DNA plastid kloroplas yang memiliki variasi tinggi serta mudah teramplifikasi serta mempunyai tingkat resolving yang cukup baik pada tingkat spesies (Kress, W.J., García-Robledo, C., Uriarte, M., \& Erickson, D.L., 2015). Gao, T., Ma, X., \& Zhu, X., (2013) menyatakan bahwa ukuran rata-rata hasil PCR $p s b A$ trnH intergenic spacer pada tanaman dari famili Fabaceae berada pada kisaran 249515 bp. Daerah psbA-trnH intergenic spacer merupakan daerah yang pendek sehingga keberhasilan amplifikasinya tinggi (100\%), sesuai dengan hasil penelitian $\mathrm{Yu}$ M., Jiao, L., Guo, J., Wiedenhoeft, A.C., He, T., Jiang, X., \& Yin, Y., (2017).

Variasi genetik pada daerah $p s b A-t r n H$ intergenic spacer cukup tinggi menurut $\mathrm{Du}$, Z.Y., Qimike, A., Yang, C.F., Chen, J.M., \& Wang, Q.F., (2011) karena terdapat banyak InDel dan homopolymer run. Homopolymer run sendiri merupakan basa nukleotida tunggal yang berulang atau mikrosatelit mononukleotida (Denver, D.R., Morris, K., Kewalramani, A., Harris,
K.E., Chow, A., Estes, S., Lynch, M., \& Thomas, W.K., 2004). Sementara itu, daerah tersebut mampu membedakan tanaman yang memiliki taksa yang berdekatan, seperti sengon dan sengon merah. Hal tersebut sesuai dengan penelitian Kamiya, K., Harada, K., Nanami, S., Itoh, A., \& Diway, B.M., (2016) yang menyatakan bahwa daerah tersebut mampu mengidentifikasi jenis-jenis dengan kekerabatan sangat dekat. Perbedaan pada 27 situs dan penyejajaran dengan sekuens plastid sengon menunjukkan bahwa sengon yang tidak terserang karat tumor di lapangan merupakan satu spesies yang sama dengan yang terserang karat tumor, yaitu F. moluccana dan berbeda dengan sengon merah A. chinensis.

Hasil penelitian ini berbeda dengan penelitian pada tanaman kakao dengan beberapa tipe fenotipe di Soconusco, Meksiko, yang juga merupakan tanaman budi daya tetapi memiliki 12 haplotipe menggunakan penanda yang sama dengan yang digunakan dalam penelitian ini (Gutiérrez-López, N., Ovando-Medina, I., Salvador-Figueroa, M., Molina-Freaner, F., Avendaño-Arrazate, C.H., \& VázquezOvando, A., 2016). Sampel resisten dan rentan dengan kode B1_R dan B1_S, yang merupakan sampel dari satu plot yang sama di Bogor juga dianalisis transkriptomnya menggunakan metode Next-generation sequencing (NGS) menunjukkan bahwa kedua sampel resisten dan rentan tersebut memiliki ekspresi gen yang berbeda 
(Shabrina, H., Siregar, U.J., Matra, D.D., Siregar, I.Z., 2019). Sengon dalam penelitian ini hanya memiliki satu macam haplotipe berdasarkan sekuens daerah psbA-trnH intergenic spacer. Meskipun berasal dari dua tipe individu (rentan dan resisten) serta dari wilayah yang berbeda, hasil penelitian ini menunjukkan bahwa terkadang haplotipe berdasarkan daerah tertentu tidak terkait dengan sifat fenotipe (Buntjer, J.B., Sørensen, A.P., \& Peleman, J.D., 2005) dalam hal ini sifat resistensi tanaman.

Keragaman genetik yang tinggi merupakan salah satu potensi resistensi tanaman menghadapi laju evolusi patogen yang jauh lebih cepat. Sementara itu, erosi genetik yang merupakan efek samping dari kegiatan budi daya tanpa memperhatikan keragaman genetik akan menyebabkan hilangnya keragaman dan sifat penting, termasuk resistensi (Liu et al., 2016). Sementara itu, keragaman genetik sengon di hutan tanaman khususnya di Pulau Jawa cenderung rendah (Siregar \& Olivia, 2012; Yuskianti \& Shiraishi, 2017). Tidak adanya variasi haplotipe dan keragaman genetik yang rendah kemungkinan disebabkan oleh rendahnya keragaman genetik pada populasi asal benih yang ditanam (Akinnagbe, et al., 2019).

\section{KESIMPULAN DAN SARAN}

\section{A. Kesimpulan}

Penggunaan penanda daerah $p s b A$ trnH intergenic spacer mengkonfirmasi bahwa sengon yang terserang dan tidak terserang karat tumor merupakan jenis Falcataria moluccana dengan haplotipe yang sama. Perbedaan genetik sengon dan sengon merah, yaitu terdapat pada 27 situs yang berbeda dari 380 situs pada daerah psbA-trnH intergenic spacer dengan jarak genetik antar dua spesies tersebut yaitu 0,017. Haplotipe yang diperoleh dari penelitian kemungkinan tidak terkait dengan sifat fenotipe resistensi terhadap karat tumor.

\section{B. Saran}

Perlu dilakukan analisis terhadap sampel sengon terserang dan tidak terserang karat tumor dari populasi lain serta penggunaan penanda plastid yang lebih banyak.

\section{UCAPAN TERIMA KASIH}

Terima kasih kepada KEMENRISTEKDIKTI RI 2016-2019 yang telah mendanai penelitian ini melalui hibah dana kompetitif skema penelitian Program Magister Menuju Doktor untuk Sarjana Unggul (PMDSU). Terima kasih kepada Bapak Adung dan Bapak Edi Pramudia (Bogor), Bapak Mod (Ciamis) yang telah membantu dalam pengumpulan sampel. Terima kasih kepada Dr. Koichi Kamiya dan Ehime University yang telah memberikan kesempatan untuk melakukan analisis laboratorium.

\section{DAFTAR PUSTAKA}

Akinnagbe, A., Gailing, O., Finkeldey, R., \& Lawal, A. (2019). Towards conservation of genetic variation of tropical tree species with differing successional status: The case of Mansonia altissima A. Chev and Triplochiton scleroxylon K. Schum. Tropical Conservation Science, 12, 19 https://doi.org/10.1177/19400829198 64267.

Artati, Y., Jaung, W., Juniwaty, K.S., Andini, S., Lee, S.M., Segah, H., \& Baral, H. (2019). Bioenergy production on degraded land: Landowner perceptions in Central Kalimantan, Indonesia. Forests, 10(2), $1-12$. https://doi.org/10.3390/f10020099

Badan Pusat Statistik. (2018). Statistik Produksi kehutanan 2017. Jakarta: Badan Pusat Statistik.

Badan Pusat Statistik. (2019). Statistik Produksi Kehutanan 2018. Jakarta: Badan Pusat Statistik. 
Baskorowati, L., \& Husna Nurrohmah, S. (2011). Variasi ketahanan terhadap penyakit karat tumor pada sengon tingkat semai. Jurnal Pemuliaan Tanaman Hutan, 5(3), 129-138. https://doi.org/10.20886/jpth.2011.5.3 $.129-138$

Baskorowati, L., Susanto, M., \& Charomaini, M. (2012). Genetic variability in resistance of Falcataria moluccana (Miq.) Barneby \& J.W. Grimes to gall rust disease. Indonesian Journal of Forestry Research, 9(1), 19.

https://doi.org/10.20886/ijfr.2012.9.1. $1-9$

Bhat, H., \& Kumar, N. (2010). On the derivation of the Bayesian Information Criterion. Akses tanggal 14 Juli 2020, dari

http://nscs00.ucmerced.edu/ nkumar4 /BhatKumarBIC.pdf

Budiman, B., \& Rianti, I.P. (2012). Teknik Pengendalian Penyakit Karat Puru Pada Pohon Sengon Gambaran Umum Karat Puru Penyebab Penyakit Karat Puru Sejarah Penyakit Karat Puru. Akses tanggal 21 Mei 2016, dari http://bp2sdmk.dephut.go.id/emagazin e/index.php/teknis/25-teknikpengendalian-penyakit-karat-purupada-pohon-sengon.htm

Buntjer, J.B., Sørensen, A.P., \& Peleman, J.D. (2005). Haplotype diversity: The link between statistical and biological association. Trends in Plant Science, 10(10), 466-471. https://doi.org/10.1016/j.tplants.2005. 08.007 .

Denver, D.R., Morris, K., Kewalramani, A., Harris, K.E., Chow, A., Estes, S., Lynch, M., \& Thomas, W.K. (2004). Abundance, distribution, and mutation rates of homopolymeric nucleotide runs in the genome of Caenorhabditis elegans. Journal of Molecular Evolution, 58(5), 584-595. https://doi.org/10.1007/s00239-0042580-4.

Diniyati, D., Achmad, B., \& Santoso, H.B.
(2013). Analisis finansial agroforestry sengon di Kabupaten Ciamis (Study kasus di Desa Ciomas Kecamatan Panjalu). Jurnal Penelitian Agroforestry, 1(1), 13-30.

Doungsa-ard, C., McTaggart, A.R., Geering, A.D.W., Dalisay, T.U., Ray, J., \& Shivas, R.G. (2015). Uromycladium falcatarium sp. nov., the cause of gall rust on Paraserianthes falcataria in southeast Asia. Australasian Plant Pathology, 44(1), 25-30. https://doi.org/10.1007/s13313-0140301-Z

Du, Z.Y., Qimike, A., Yang, C.F., Chen, J.M., \& Wang, Q.F. (2011). Testing four barcoding markers for species identification of Potamogetonaceae. Journal of Systematics and Evolution, 49(3),

246-251. https://doi.org/10.1111/j.17596831.2011.00131.x.

Gao, T., Ma, X., \& Zhu, X. (2013). Use of the psbA-trnH region to authenticate medicinal species of Fabaceae. Biological and Pharmaceutical Bulletin, 36(12), 1975-1979. https://doi.org/10.1248/bpb.b1300611.

Genetyx Corporation. (2015). GENETYX Ver. 13. Akses tanggal 20 Desember 2018, dari https://www.genetyx.co.jp/updates/ge netyx_13

Gutiérrez-López, N., Ovando-Medina, I., Salvador-Figueroa, M., MolinaFreaner, F., Avendaño-Arrazate, C.H., \& Vázquez-Ovando, A. (2016). Unique haplotypes of cacao trees as revealed by trnH-psbA chloroplast DNA. PeerJ, 2016(4), 1-18. https://doi.org/10.7717/peerj.1855.

Hamilton, M.B. (1999). Four primer pairs for the amplification of chloroplast intergenic regions with intraspecific variation. Molecular Ecology, 8(3), 521-523.

http://www.ncbi.nlm.nih.gov/pubmed/ 10199016. 
Hardiatmi, S.J. . (2010). Investasi tanaman kayu sengon dalam wanatani cukup menjanjikan. Jurnal Inovasi Pertanian, 9(2), 17-21.

Huang, X.C., Ci, X.Q., Conran, J.G., \& Li, J. (2015). Application of DNA barcodes in Asian tropical trees - A case study from Xishuangbanna Nature Reserve, Southwest China. PLoS ONE, 10(6), 1-17. https://doi.org/10.1371/journal.pone.0 129295.

Hurvich, C.M., \& Tsai, C.L. (1993). A corrected akaike information criterion for vector autoregressive model selection. Journal of Time Series Analysis, 14(3), 271-279. https://doi.org/10.1111/j.14679892.1993.tb00144.x.

Iskandar, B.S., Iskandar, J., \& Partasasmita, R. (2018). Strategy of the outer baduy community of South Banten (Indonesia) to sustain their swidden farming traditions by temporary migration to non-baduy areas. Biodiversitas, 19(2), 453-464. https://doi.org/10.13057/biodiv/d1902 12.

Kamiya, K., Harada, K., Nanami, S., Itoh, A., \& Diway, B.M. (2016). Molecular phylogeny and evolution of tropical forest trees. Proceedings of the Symposium "Frontier in Tropical Forest Research: Progress in Joint Projects between the Forest Department Sarawak and the Japan Research Consortium for Tropical Forests in Sarawak," 30-37. http://hdl.handle.net/2433/227106.

Kress, W.J., García-Robledo, C., Uriarte, M., \& Erickson, D.L. (2015). DNA barcodes for ecology, evolution, and conservation. Trends in Ecology and Evolution, 30(1), 25-35. https://doi.org/10.1016/j.tree.2014.10. 008.

Kress, W. J. (2017). Plant DNA barcodes: Applications today and in the future. Journal of Systematics and Evolution, 55(4), 291-307. https://doi.org/10.1111/jse.12254.

Krisnawati, H., Varis, E., Kallio, M., \& Kanninen, M. (2011). Paraserianthes falcataria (L.) Nielsen: Ekologi, silvikultur dan produktivitas. In Paraserianthes falcataria (L.) Nielsen: Ekologi, silvikultur dan produktivitas. CIFOR. https://doi.org/10.17528/cifor/003482.

Kumar, S., Stecher, G., Li, M., Knyaz, C., \& Tamura, K. (2018). MEGA X: Molecular evolutionary genetics analysis across computing platforms. Molecular Biology and Evolution, 35(6), 1547-1549. https://doi.org/10.1093/molbev/msy09 6.

Lelana, N.I. (2018). Epidemiologi dan Keragaman Patogen Karat Puru Sengon Di Indonesia. Disertasi. IPB University, Bogor.

Liu, H.L., Zhang, R.Q., Geng, M.L., Zhu, J.Y., An, J.C., \& Ma, J.L. (2016). Chloroplast analysis of Zelkova schneideriana (Ulmaceae): Genetic diversity, population structure, and conservation implications. Genetics and Molecular Research, 15(1), 1-9. https://doi.org/10.4238/gmr.15017739

Neubig, K.M., Whitten, W.M., Williams, N.H., Blanco, M.A., Endara, L., Burleigh, J.G., Silvera, K., Cushman, J.C., \& Chase, M.W. (2012). Generic recircumscriptions of oncidiinae (Orchidaceae: Cymbidieae) based on maximum likelihood analysis of combined DNA datasets. Botanical Journal of the Linnean Society, 168(2), 117-146. https://doi.org/10.1111/j.10958339.2011.01194.x.

Newmaster, S.G., \& Ragupathy, S. (2009). Testing plant barcoding in a sister species complex of pantropical Acacia (Mimosoideae, Fabaceae). Molecular Ecology Resources, 9(SUPPL. 1), 172180. https://doi.org/10.1111/j.17550998.2009.02642.x.

Ota, M. (2019). From joint forest 
management to more smallholderbased community forestry: prospects and challenges in Java, Indonesia. Journal of Forest Research, 24(6), 371-375.

https://doi.org/10.1080/13416979.201 9.1685063.

Pang, X., Liu, C., Shi, L., Liu, R., Liang, D., Li, H., Cherny, S.S., \& Chen, S. (2012). Utility of the trnH-psbA intergenic spacer region and its combinations as plant DNA barcodes: A meta-analysis. PLoS ONE, 7(11), 19.

https://doi.org/10.1371/journal.pone.0 048833.

Purnomo, D., Budiastuti, M.S., Sakya, A.T., \& Cholid, M.I. (2018). The potential of turmeric (Curcuma xanthorrhiza) in agroforestry system based on silk tree (Albizia chinensis). IOP Conference Series: Earth and Environmental Science, $142(1), \quad 12034$. https://doi.org/10.1088/1755-

1315/142/1/012034.

Reyeki, S. (2013). Pemanfaatan serbuk gergaji kayu sengon (Albizia falcataria) dan bekatul sebagai media tanam budidaya jamur tiram putih (Pleurotus ostreatus) dengan penambahan serbuk sabut kelapa (Cocos nucifera). Skripsi. Universitas Muhammadiyah Surakarta, Surakarta.

Rohandi, A., \& Gunawan. (2019). Ketahanan sengon provenan Papua umur 2 tahun terhadap karat tumor pada uji resistensi di Ciamis, Jawa Barat. Jurnal Agroforestri Indonesia, 2(1), 37-50. https://doi.org/10.20886/jai.2019.2.1. 37-50.

Rozas, J., Ferrer-Mata, A., SanchezDelBarrio, J.C., Guirao-Rico, S., Librado, P., Ramos-Onsins, S.E., \& Sanchez-Gracia, A. (2017). DnaSP 6: DNA sequence polymorphism analysis of large data sets. Molecular Biology and Evolution, 34(12), 32993302.

https://doi.org/10.1093/molbev/msx24
8.

Sehn, J.K. (2015). Insertions and deletions (indels). In Clinical Genomics (pp. 129-150). Elsevier. https://doi.org/10.1016/B978-0-12404748-8.00009-5.

Setiadi, D., Susanto, M., \& Baskorowati, L. (2014). Ketahanan serangan penyakit karat tumor pada uji keturunaan sengon (Falcataria moluccana) di Bondowoso, Jawa Timur. Jurnal Pemuliaan Tanaman Hutan, 8(1), 113.

Shabrina, H. (2020). Pendekatan genomika ekologi untuk pemuliaan sengon (Falcataria moluccana) resisten karat tumor (Uromycladium falcatarium). Disertasi. IPB University, Bogor.

Shabrina, H., Siregar, U.J., Matra, D.D., Kamiya, K., \& Siregar, I.Z. (2019). Short communication: DNA extraction from stored wood of Falcataria moluccana suitable for barcoding analysis. Biodiversitas, 20(6), 17481752. https://doi.org/10.13057/biodiv/d2006 35.

Shabrina, H., Siregar, U.J., Matra, D.D., \& Siregar, I.Z. (2019). The dataset of de novo transcriptome assembly of Falcataria moluccana cambium from gall-rust (Uromycladium falcatarium) infected and non- infected tree. Data in Brief, 26, 4-7.

Siregar, U.J., \& Olivia, R.D. (2012). Keragaman genetik populasi sengon (Paraserianthes falcataria (L) Nielsen) pada hutan rakyat di Jawa berdasarkan penanda RAPD. Jurnal Silvikultur Tropika, 3(2), 1-7.

Štorchová, A.H., \& Olson, M.S. (2007). The architecture of the chloroplast psbA-trnH non-coding region in angiosperms. Plant Systematics and Evolution, 268(1), 235-256.

Surjosatyo, A., Dewantoro, B.R., Saragih, B.R., Nainggolan, F., Dwianto, W., \& Darmawan, T. (2018). Selecting and testing of wind turbine blades of the local-wood growing fastly on local 
wind characteristics. IOP Conference Series: Earth and Environmental Science, $\quad 105(1), \quad 12095$. https://doi.org/10.1088/17551315/105/1/012095.

Tamura, K. (1992). Estimation of the number of nucleotide substitutions when there are strong transitiontransversion and $\mathrm{G}+\mathrm{C}$-content biases. Molecular Biology and Evolution, 9(4), 678-687. https://doi.org/10.1093/oxfordjournals .molbev.a040752.

The International Tropical Timber Organization. (2020a). Albizia (Albizia chinensis). Akses tanggal 11 Februari 2020, dari http://www.tropicaltimber.info/specie/ albizia-albizia-chinensis/

The International Tropical Timber Organization. (2020b). Falcata (Paraserianthes falcataria). Akses tanggal 11 Februari 2020, dari http://www.tropicaltimber.info/specie/ falcata-paraserianthes-falcataria/

US Forest Service Pacific Island Ecosystems Risk. (2013). Albizia chinensis (Osbeck). Akses tanggal 3 Januari 2020, dari http://www.hear.org/pier/species/albiz ia_chinensis.htm.

US Forest Service Pacific Island Ecosystems Risk. (2018). Falcataria moluccana. Akses tanggal 3 Januari 2020 , dari http://www.hear.org/pier/species/falca taria_moluccana.htm.

Utomo, S.W., Sudarna, \& Pratiwi, D.M. (2019). Revisit the green barrier development for ammonia exposure preventive countermeasure at urea fertilizer Z Factory in South Sumatera, Indonesia. IOP Conference Series: Earth and Environmental Science, 399(1), 12093. https://doi.org/10.1088/17551315/399/1/012093.

Werle, E., Schneider, C., Renner, M., Volker, M., \& Fiehn, W. (1994). Convenient single-step, one tube purification of PCR products for direct sequencing. Nucleic Acids Research, 22(20), 4354-4355.

Withaningsih, S., Parikesit, Iskandar, J., \& Putri, R. (2019). Socio-ecological perspective of local bio-resources based production system of palm sugar and palm flour from aren (Arenga pinnata): Case study of Sukaresmi Village, West Bandung, Indonesia. Biodiversitas, 20(7), 1990-1997. https://doi.org/10.13057/biodiv/d2007 27.

Yu, M., Jiao, L., Guo, J., Wiedenhoeft, A.C., He, T., Jiang, X., \& Yin, Y. (2017). DNA barcoding of vouchered xylarium wood specimens of nine endangered Dalbergia species. Planta, 246(6), 1165-1176. https://doi.org/10.1007/s00425-0172758-9

Yu, M., Liu, K., Zhou, L., Zhao, L., \& Liu, S. (2016). Testing three proposed DNA barcodes for the wood identification of Dalbergia odorifera T. Chen and Dalbergia tonkinensis Prain. Holzforschung, 70(2), 127-136. https://doi.org/10.1515/hf-2014-0234.

Yuskianti, V., \& Shiraishi, S. (2017). Genetic diversity and genetic relationship of sengon (Falcataria moluccana) revealed using single nucleotide polymorphism (SNP) markers. Indonesian Journal of Forestry Research, 4(2), 85-94. https://doi.org/10.20886/ijfr.2017.4.2. 85-94.

Zhang, R., Wang, Y.H., Jin, J.J., Stull, G.W., Bruneau, A., Cardoso, D., De Queiroz, L.P., Moore, M. J., Zhang, S.D., Chen, S.Y., Wang, J., Li, D.Z., Yi, T.S., \& Smith, S. (2020). Exploration of Plastid Phylogenomic Conflict Yields New Insights into the Deep Relationships of Leguminosae. Systematic Biology, 69(4), 613-622. https://doi.org/10.1093/sysbio/syaa01 3. 